\title{
Plot size variation to quantify yield of potato clones
}

\author{
Dilson Antônio Bisognin; Lindolfo Storck; Liege C da Costa; Maurício G Bandinelli \\ UFSM-Depto. Fitotecnia, Av. Roraima s/nº, Bairro Camobi, 97105-900 Santa Maria-RS; E-mail: dilsonb@smail.ufsm.br; \\ lindolfo@smail.ufsm.br
}

\begin{abstract}
The objective of this paper was to study plot size variation among potato clones to increase experimental precision of yield performance trials. The experiment was carried out at the experimental area of the Horticulture Dept., UFSM, Santa Maria, Rio Grande do Sul State, Brazil. Tubers of five potato clones were planted in two rows of 60 hills in August 2004. For all ten experimental rows, combined plots were formed adding a different number of adjacent hills of the same row. Soil heterogeneity index and optimum plot size were estimated for each row. Real differences between treatment means for each clone and all clones were estimated using the Hatheway technique. The experimental precision of potato yield trials varied with the evaluated clone because of different optimum plot sizes. Eight-hill plots are the optimum size to quantify yield of potato clones, but experimental precision depends upon adjustments of the number of treatments and replications to the availability of experimental area. Genetic diversity indeed decreases experimental precision and justifies the use of different plot sizes. Practical applicattions and strategies to increase experimental precision of yields performance trials of potato clones are discussed.
\end{abstract}

Keywords: Solanum tuberosum; experimental planning; plot size; limited experimental area.

\begin{abstract}
RESUMO
Variação do tamanho de parcela para acessar o rendimento de clones de batata

O objetivo deste trabalho foi estudar a variação do tamanho de parcela entre clones de batata visando aumentar a precisão experimental nos ensaios de avaliação de rendimento. Tubérculos de cinco clones de batata foram plantados em duas fileiras de 60 covas na área experimental do Depto. de Fitotecnia-UFSM, em Santa MariaRS, em agosto de 2004. Para cada uma das 10 fileiras do experimento foram planejadas parcelas de diferentes tamanhos, agrupando os resultados de covas adjacentes dentro da mesma fileira. Foram estimados o índice de heterogeneidade do solo e o tamanho ótimo da parcela. A diferença verdadeira entre médias de tratamentos, para cada clone e no geral foi estimada pelo método de Hatheway. A precisão experimental para acessar o rendimento de batata varia com o clone avaliado, devido às diferenças no tamanho ótimo de parcela. O tamanho ótimo de parcela é de oito covas, sendo que a precisão experimental depende do número de tratamentos e do número de repetições ajustados para a área disponível. Aplicações práticas e estratégias para aumentar a precisão experimental de ensaios de rendimento de clones de batata são discutidas.
\end{abstract}

Palavras-chave: Solanum tuberosum; planejamento de experimento; tamanho de parcela; área experimental limitada.

(Recebido para publicação em 2 de fevereiro de 2006; aceito em 6 de dezembro de 2006)

$\mathrm{P}$ otato breeding programs generate many advanced new clones that need to be selected for yield potential and adaptation every year. This is a very important breeding step that requires high experimental precision to identify the best clones. Experimental precision involves experimental design, optimum plot size and adequate replication number adjusted to the availability of experimental area (Martin et al., 2004).

Optimum plot size have been estimated based upon yield data of uniformity trials (Cordeiro et al., 1982; Oliveira \& Estefanel, 1995; Bearzoti \& Pinto, 1996; Oliveira, 2005) and trials with a wide-rang of treatments in which sub-plots were harvested (Vermeer, 1990). The level of soil heterogeneity affects both plot size and replication number, because of yield variation (Smith, 1938; Hatheway, 1961; Lin \& Binns, 1986; Martin et al., 2004;
Oliveira, 2005). Yield variation among plots depend upon genetic diversity (Brown, 1987), environmental conditions, inter and intra-plot competition and sampling technique (Smith, 1938; Gomez \& Gomez, 1984; Steel et al., 1997).

The persistence of the soil heterogeneity index and the optimum plot size is about $50 \%$ in subsequent years of a particular crop (Lin et al., 1996). Since exact knowledge about the environmental variability of the experimental area is necessary to arrange more precise experiments, only unbiased estimations should be used to improve gain from selection in a particular step of the potato breeding program (Vermeer, 1990). Single-hill plots are not precise enough to detect differences among clones already selected in previous generations (Brown, 1987). Moreover, plots bigger than single hills are necessary to detect differences among clones in advanced selection steps (Bearzoti \& Pinto, 1996).

The objective of this paper was to study plot size variation among potato clones to increase experimental precision of yield performance trials. Practical applications and strategies to increase experimental precision of yield performance trials of potato clones are discussed.

\section{MATERIAL AND METHODS}

Five potato clones ('SMIJ456-4Y', 'SMINIA95043-11', 'SMINIA-Iporã', 'Macaca' and 'SMINIA90244-1') differing in vine maturity, vigor and adaptation to local growing conditions were evaluated. High quality seed tubers of each clone were planted in two rows of 60 hills at the experimental area of the Horticulture Dept. of UFMS in Santa Maria, Rio Grande do Sul State, Brazil, on August $11^{\text {th }}, 2004$. One seed tuber 
Table 1. Summary of variance analysis, clonal and trial averages and coeficient of variation for tuber yield ( $\mathrm{g} \mathrm{hill}^{-1}$ ) of five potato clones. Santa Maria-RS, UFSM, 2004.

\begin{tabular}{|c|c|c|}
\hline Sources of variation & DF & Mean square \\
\hline Clones & 4 & 213799.22 \\
\hline Experimental error & 5 & $39555.52^{\text {ns }}$ \\
\hline Sample error & 590 & 28405.21 \\
\hline Average & - & 270.60 \\
\hline Coeficiente of variation & - & $73.5 \%$ \\
\hline Clones & \multicolumn{2}{|c|}{ Average (g hill-1) } \\
\hline SMINIA-Iporã & \multicolumn{2}{|c|}{$322.67 \mathrm{a}^{(2)}$} \\
\hline SMINIA95043-11 & \multicolumn{2}{|c|}{$297.83 a b$} \\
\hline SMINIA90244-1 & \multicolumn{2}{|c|}{$268.04 \mathrm{abc}$} \\
\hline Macaca & \multicolumn{2}{|c|}{$251.24 \mathrm{bc}$} \\
\hline SMIJ456-4Y & \multicolumn{2}{|c|}{$213.22 c$} \\
\hline
\end{tabular}

${ }^{1}$ Significant by the test $\mathrm{F}$ at $5 \%$ probability; ${ }^{\text {ns }}$ not significant; ${ }^{2}$ Clone averages not followed by the same letter differ by the Duncan's test at 5\% probability.

was considered a hill. Hills were separated by $0.80 \mathrm{~m}$ between rows and $0.30 \mathrm{~m}$ within rows. Soil and crop managements were uniform and followed technical recommendations adapted in the regions. Tubers were harvested on November $19^{\text {th }}, 2004$ and total yield per hill quantified.

Each hill was considered one basic unit (BU) plot. Adding adjacent hills or $\mathrm{BU}$ of the same row produced combined plots. Combined plot size (X) was defined as the number of basic units or BU. Combined plots had X equal to 1 , $2,3,4,5,6,10,12$ and $15 \mathrm{BU}$, in each row. The total number of replications (N) of each combined plot was limited to 60 hills, meaning $\mathrm{N}=60 / \mathrm{X}$. Some statistics were estimated for each combined plot. Plot mean $\mathrm{M}(\mathrm{x})$ with $\mathrm{X}$ $\mathrm{BU}$, where $\mathrm{M}(1)$ or $\mathrm{M}_{1}$ was the average of one BU. Variance $\mathrm{V}(\mathrm{x})$, for each combined plot of $\mathrm{X}$ BU. The variance per BU, VU(x), for plot sizes of X BU, where $\mathrm{VU}(\mathrm{x})=\mathrm{V}(\mathrm{x}) / \mathrm{X}^{2}$. Coefficient of variance $\mathrm{CV}(\mathrm{x})$ for plot sizes of $\mathrm{X} B U$.

The parameters $V_{1}$ and $b$ of the empirical relationship $\mathrm{VU}(\mathrm{x})=\mathrm{V}_{1} / \mathrm{X}^{\mathrm{b}}$ (Smith, 1938) were estimated based upon logarithmic transformation and weighted according to degrees of freedom for each plot size (Steel et al., 1997). $V_{1}$ was the variance of one basic unit plots and $b$ the soil heterogeneity index.

The same procedure was used to estimate the $\mathrm{A}$ and $\mathrm{B}$ parameters of the function $\mathrm{CV}(\mathrm{x})=\mathrm{A} / \mathrm{X}^{\mathrm{B}}$. The optimum plot size $\left(\mathrm{X}_{0}\right)$ was estimated with the modified maximum curvature technique (Meier \& Lessman, 1971)

$$
X_{0}=\exp \left\{\left(\frac{1}{2 B+2}\right) \ln \left[\frac{A^{2} B^{2}(2 B+1)}{B+2}\right]\right\} \text {. }
$$

The logarithmic transformation of the function $\mathrm{CV}(\mathrm{x})=\mathrm{A} / \mathrm{X}^{\mathrm{B}}$ that resulted in the model $Y=\alpha_{k}+\beta_{k} X+\varepsilon$ for both replications of $\mathrm{k}$, varying from 1 to 5 clones, was used to test parallelism, $\left(H_{01}: \beta_{1}=\beta_{2}=\ldots=\beta_{K}\right) \quad$ same origin $\left(\mathrm{H}_{02}: \alpha_{1}=\alpha_{2}=\ldots=\alpha_{\mathrm{K}}\right)$ and coincidence $\left(H_{03}: \alpha_{1}=\alpha_{2}=\ldots=\alpha_{K}, \beta_{1}=\beta_{2}=\ldots=\beta_{K}\right)$ among the five clones (Seber, 1976). The approximate statistic of the hypothesis test

$$
\begin{aligned}
& F_{c}=\frac{\left(S Q E_{H o}-\sum_{k}^{K} S Q E_{k}\right) /(K-1)}{\sum_{k}^{K} S Q E_{k} /(n-2 K)} \\
& \text { for } \mathrm{H}_{01} \text { and } \mathrm{H}_{02} \text {, and } \\
& F_{c}=\frac{\left(S Q E_{H o}-\sum_{k}^{K} S Q E_{k}\right) /(2 K-2)}{\sum_{k}^{K} S Q E_{k} /(n-2 K)}
\end{aligned}
$$

for $\mathrm{H}_{03}$, where $\mathrm{SQE}_{\mathrm{HO}}$ was the combined sum square error; $\sum_{k}^{K} S Q E_{k}$ was the sum of the sum square error of each clone; $\mathrm{K}$ was the number of compared clones $(K=5)$; and $n$ was the number of total observations (plot sizes and replications).

The magnitude of treatment differences, expressed as mean percentage (D) of each and all clones, was estimated with $D=\sqrt{2\left(t_{1}+t_{2}\right)^{2} A^{2} / r X_{o}^{b}}$, where $r$ was the number of replications; $\mathrm{X}_{0}$ was the optimum plot size (number of BU); A was estimated with the function $\mathrm{CV}(\mathrm{x})=\mathrm{A} / \mathrm{X}^{\mathrm{B}}$ and $\mathrm{b}$ estimated with the function $\mathrm{VU}(\mathrm{x})=\mathrm{V}_{1} / \mathrm{X}^{\mathrm{b}} ; \mathrm{t}_{1}$ was the value of $t$ in the test of significance (bilateral at $5 \%$ ) and $t_{2}$ was the value of $\mathrm{t}$ in the table corresponding to 2(1-P), where $\mathrm{P}$ was the probability of obtaining a significant result $(0,80)$ (Hatheway, 1961). The table value of the $t$ distributions was obtained with degrees of freedom (DF) considering a complete random design, $\mathrm{DF}=\mathrm{I}(\mathrm{r}-1)$. The number of treatments (I) was designed as five and the replication number (r) obtained with the relationship between hill number of two rows (120) and optimum plot size (Xo). This relationship was done for each and all clones to fit the available experimental area.

The statistical analysis was done considering a complete random design with total plot sampling. Mean comparisons were done with Duncan's test. All analysis was done with the software NTIA (Embrapa, 1997) and FORTRAN language software (AbouEl-Fittouh et al., 1974) adapted to estimate mean and variance of different plot sizes.

\section{RESULTS AND DISCUSSION}

The five evaluated clones differed in yield per hill, even though the coefficient of variation was high $(73.5 \%)$. The variation between the highest and the lowest yield per hill was $109.45 \mathrm{~g} \mathrm{hill}^{-1}$, which is equivalent to approximately $4,560 \mathrm{~kg} \mathrm{ha}^{-1}$ (Table 1). Considering that the experimental error was not significant, variation among hills was similar to replicate variation (total of 60 hills). Therefore, it is more important to increase the number of replications than plot size (number of basic units) to improve experimental precision.

In all experimental rows, increasing combined plot size by increasing the number of basic units reduced the coefficient of variation, the variation between maximum and minimum value as well as the ratio between maximum and minimum (Table 2).

The parameter estimates of the functions $\mathrm{VU}(\mathrm{x})=\mathrm{V}_{1} / \mathrm{X}^{\mathrm{b}}$ and $\mathrm{CV}(\mathrm{x})=\mathrm{A} /$ 
Table 2. Coefficient of variation of basic and combined plots of different size (X) of five potato clones cultivated in two rows of 60 hills. Santa Maria-RS, UFSM, 2004.

\begin{tabular}{|c|c|c|c|c|c|c|c|c|c|c|}
\hline \multicolumn{11}{|c|}{ Potato Clones } \\
\hline \multirow[b]{2}{*}{$x$} & \multicolumn{2}{|c|}{ 'SMIJ456-4Y' } & \multicolumn{2}{|c|}{ 'SMINIA95043-11' } & \multicolumn{2}{|c|}{ 'SMINIA-Iporã' } & \multicolumn{2}{|c|}{ 'Macaca' } & \multicolumn{2}{|c|}{ 'SMINIA90244-1' } \\
\hline & Row 1 & Row 2 & Row 1 & Row 2 & Row 1 & Row 2 & Row 1 & Row 2 & Row 1 & Row 2 \\
\hline 1 & 60.86 & 74.45 & 61.87 & 85.63 & 54.52 & 50.97 & 43.73 & 67.23 & 57.74 & 62.18 \\
\hline 2 & 47.03 & 56.57 & 46.75 & 67.25 & 37.18 & 37.54 & 27.82 & 48.93 & 35.23 & 51.89 \\
\hline 3 & 34.09 & 54.20 & 34.69 & 52.42 & 28.47 & 31.16 & 25.28 & 44.73 & 34.69 & 46.34 \\
\hline 4 & 32.89 & 42.37 & 33.80 & 44.14 & 27.16 & 27.32 & 22.24 & 44.02 & 25.84 & 45.98 \\
\hline 5 & 33.75 & 43.32 & 32.12 & 46.89 & 30.81 & 23.34 & 21.36 & 33.89 & 24.15 & 44.17 \\
\hline 6 & 29.24 & 38.31 & 27.56 & 39.34 & 23.27 & 23.91 & 19.88 & 38.49 & 22.77 & 43.52 \\
\hline 10 & 16.27 & 36.62 & 27.82 & 24.46 & 15.06 & 17.45 & 9.27 & 27.68 & 20.90 & 40.13 \\
\hline 12 & 19.68 & 32.11 & 25.38 & 36.33 & 14.20 & 20.44 & 14.96 & 30.04 & 21.54 & 41.90 \\
\hline 15 & 14.93 & 22.70 & 27.87 & 36.04 & 11.41 & 18.91 & 15.84 & 21.06 & 20.66 & 42.93 \\
\hline
\end{tabular}

Table 3. Tuber yield $(\mathrm{g})$ per hill $\left(\mathrm{M}_{1}\right)$, parameter estimations of the functions $\mathrm{VU}(\mathrm{x})=\mathrm{V}_{1} / \mathrm{X}^{\mathrm{b}}$ and $\mathrm{CV}(\mathrm{x})=\mathrm{A} / \mathrm{X}^{\mathrm{B}}$, coeficient of determination $\left(\mathrm{R}^{2}\right)$ and optimum plot size estimated with the modified maximum curvature technique (Xo) of five potato clones cultivated in two rows of 60 hills. Santa Maria-RS, UFSM, 2004.

\begin{tabular}{lcccccccc}
\hline Clones & Rows & M1 & V1 & b & A & B & R2 & Xo \\
\hline 'SMIJ456-4Y' & 1 & 206.6 & 22136.6 & 1.137 & 72.0 & 0.568 & 0.901 & 10 \\
'SMIJ456-4Y' & 2 & 219.8 & 34786.9 & 0.867 & 84.8 & 0.433 & 0.833 & 11 \\
'SMINIA95043-11' & 1 & 324.9 & 22560.1 & 0.432 & 46.2 & 0.216 & 0.728 & 5 \\
'SMINIA95043-11' & 2 & 270.8 & 34485.9 & 0.572 & 68.5 & 0.286 & 0.481 & 8 \\
'SMINIA-Iporã' & 1 & 326.3 & 46723.5 & 1.262 & 66.2 & 0.631 & 0.943 & 9 \\
'SMINIA-Iporã' & 2 & 319.0 & 18273.4 & 0.633 & 42.3 & 0.316 & 0.836 & 6 \\
'Macaca' & 1 & 276.1 & 9381.8 & 0.722 & 35.0 & 0.361 & 0.465 & 5 \\
'Macaca' & 2 & 226.4 & 27850.3 & 0.844 & 73.7 & 0.422 & 0.855 & 10 \\
'SMINIA90244-1' & 1 & 283.6 & 13314.5 & 0.533 & 40.6 & 0.266 & 0.815 & 5 \\
'SMINIA90244-1' & 2 & 252.5 & 17274.3 & 0.173 & 52.0 & 0.860 & 0.604 & 3 \\
\hline
\end{tabular}

$\mathrm{X}^{\mathrm{B}}$ and optimum plot size (Xo) varied between replications of the same clone (Table 3) and among clones (Table 4). Estimation variations among clones indicated that experimental precision was dependent upon genetic diversity. The clone 'SMINIA90244-1' had the smallest and 'SMIJ456-4Y' had the biggest optimum plot size estimations among the evaluated clones. 'SMIJ456$4 \mathrm{Y}^{\prime}$ is the least adapted to the growing conditions and has the lowest vine vigor. The estimates of both $\mathrm{A}$ and $\mathrm{B}$ parameters of the function $\mathrm{CV}(\mathrm{x})=\mathrm{A}$ / $\mathrm{X}^{\mathrm{B}}$ alter optimum plot size (Oliveira, 2005) determined by the modified maximum curvature technique (Meier \& Lessman, 1971). There was no differences among clones neither in origin (A) nor parallelism (B) of the function $\mathrm{CV}(\mathrm{x})=\mathrm{A} / \mathrm{X}^{\mathrm{B}}$, but there were variation among clones in coincidence (Table 4). It happened because A and B parameters are simultaneously tested for coincidence among clones. As Xo depends on simultaneous variation of $\mathrm{A}$ and $\mathrm{B}$ parameters, the Xo estimation differed among clones.

The optimum plot size varied from four to ten hills among clones with an average of eight-hill plots (Table 4). The optimum plot size in twelve trials with the clone 'Macaca' was seven-hill plots (Oliveira, 2005). We found the same optimum plot size as average of two replications of this clone, indicating high accuracy of the results. This experiment clearly showed that differences in plot size and/or number of replications were necessary to compare clones based upon similar experimental precision (D). However, varying plot size and/or number of replications have no practical application. Therefore, a researcher should separate clones in trials with similar plot size requirements. The adoption of optimum plot size increases experimental precision and the probability of detecting differences among clones.
In this experiment, adapted clones as 'Macaca' and 'SMINIA90244-1' had lower environmental error, resulting in higher yield precision. The evaluation of these clones together with others with high environmental error would increase the coefficient of variation and reduce experimental precision. Comparing to plot size estimations of 20 and 30 hills, respectively for potato plants growing during spring and autumn seasons (Oliveira \& Estefanel, 1995), the average optimum size of eight-hill plots for five clones might be considered too small. However, the average was very close to seven-hill plots estimated for 'Macaca' in a uniform trial with 12 replications (Oliveira, 2005).

The highest experimental precision of a clone as 'SMINIA-Iporã' ( $\mathrm{D}=$ $20.4 \%$ ) can be achieved with eight-hill plots. As the experimental precision (D) depends upon the estimations of $\mathrm{A}$ and $B$ parameters or the experimental arrangement (I, r, Xo, GLe), distinct 
Table 4. Potato tuber yield $(\mathrm{g})$ per hill $\left(\mathrm{M}_{1}\right)$, parameter estimations of the functions $\mathrm{VU}(\mathrm{x})=$ $\mathrm{V}_{1} / \mathrm{X}^{\mathrm{b}}$ and $\mathrm{CV}(\mathrm{x})=\mathrm{A} / \mathrm{X}^{\mathrm{B}}$, optimum plot size $(\mathrm{Xo})$ and percentage of true differences among treatment means of each clone and all clones (D). Santa Maria-RS, UFSM, 2004.

\begin{tabular}{lccccccc}
\hline Clones & M1 & V1 & b & A & B & Xo & D \\
\hline 'SMIJ456-4Y' & 213.22 & 27749.9 & 1.002 & 78.1 & 0.501 & 10 & 28.6 \\
'SMINIA95043-11' & 297.83 & 27892.6 & 0.502 & 56.3 & 0.251 & 7 & 33.5 \\
'SMINIA-Iporã' & 322.67 & 29219.7 & 0.947 & 52.9 & 0.473 & 8 & 20.4 \\
'Macaca' & 251.24 & 16164.2 & 0.783 & 50.8 & 0.391 & 7 & 23.0 \\
'SMINIA90244-1' & 268.04 & 15165.6 & 0.353 & 46.0 & 0.176 & 4 & 26.2 \\
Mean estimates & 270.60 & 22323.6 & 0.717 & $55.8^{(1)}$ & $0.358^{(2)}$ & $8^{(3)}$ & 27.4 \\
\hline
\end{tabular}

${ }^{1}$ Clones with same origin by $\mathrm{F}$ test at $5 \%$ probability; ${ }^{2} \mathrm{Clones}$ with parallelism by $\mathrm{F}$ test at $5 \%$ probability; ${ }^{3}$ Clones without coincidence by $\mathrm{F}$ test at $5 \%$ probability.

combinations of experimental design can drastically change experimental precision. Therefore, the adoption of the same plot size (eight-hill plots) for all clones has practical applications and clone precision differences can be compensated by increasing number of replications. An area of 600 hills can be efficiently used $(D=27.4 \%)$ in an experimental arrangement of five treatments ( $I=5)$ with 15 replications of eight-hill plots. A higher number of treatments would imply a reduction in the replication number (r) to adjust the function $r=600 /(8 * I)$. The estimation of the experimental precision (D) is necessary for each number of treatments.

The experimental precision of potato yield trial varies with the evaluated clone, because of different optimum plot sizes. Eight-hill plots are the optimum size to quantify yield of potato clones, but experimental precision depends upon adjustments of the number of treatments and replications to the availability of experimental area. different plot size and numbers of replications and of plot per block. Agronomy Journal 78: 531-534.

LIN CS; MORRISON MJ; BINN MR. 1996. Persistence of a field heterogeneity index. Canadian Journal of Plant Science 76: 245250.

MARTIN TN; STORCK L; LOPES SJ; SANTOS PM; CARVALHO MP; DAMO HP. 2004. Definição do plano experimental para comparação de cultivares de milho em áreas limitadas. Revista Brasileira de Milho e Sorgo 3: 325-332.

MEIER VD; LESSMAN KJ. 1971. Estimation of optimum field plot shape and size testing yield in Crambe abyssinica hordnt. Crop Science 11: 648-650.

OLIVEIRA PH; ESTEFANEL V. 1995. Tamanho e forma ótimos da parcela para avaliação do rendimento em experimentos com batata. $\mathrm{Ci}$ ência Rural 25: 205-208.

ABOU-EL-FITTOUH HA; EL-BAKRY AE; ELSERGANY DZ.1974. A program for studying the optimum plot size in field experiments on the computer. Agricultural Research Review 52: 85-90.

BEARZOTI E; PINTO CABP. 1996. Dimensionamento de parcela em experimentos de seleção em batata (Solanum tuberosum L.). Ciência e Agrotecnologia 20: 151-159.

BROWN JÁ. 1987. Comparison between single plant plots and five plant plots for the initial selection stage of a potato breeding program. Euphytica 36: 711-718.

CORDEIRO CMT; MIRANDA JEC; CAMPOS J. 1982. Tamanho de parcelas e número de repetições em experimentos de batata. Pesquisa Agropecuária Brasileira 17: 1341-1348.

EMPRESA BRASILEIRA DE PESQUISA AGROPECUÁRIA. 1997. Ambiente de software NTIA, versão 4.2.2: manual do usuário - ferramental estatístico. Campinas: EMBRAPA, Centro Nacional de Pesquisa Tecnológica em Informática para a Agricultura. $258 \mathrm{p}$

GOMEZ KA; GOMEZ AA. 1984. Statistical procedures for agricultural research. 2.ed. New York: John Wiley. 680p.

HATHEWAY WH. 1961. Convenient plot size. Agronomy Journal 53: 279-280.

LIN CS; BINNS MR. 1986. Relative efficiency

OLIVEIRA SJR. 2005. Dependência entre o tamanho da unidade básica e as estimativas das dimensões da parcela experimental de batata. Santa Maria: UFSM. 69p. (Tese doutorado).

SEBER GAF. 1976. Linear regression analysis. NewYork: John Wiley \& Sons. 465p.

SMITH HF. 1938. An empirical law describing heterogeneity in the yields of agricultural crops. Journal of Agricultural Science 28: 123.

STEEL RGD; TORRIE JH; DICKEY DA. 1997. Principles and procedures of statistics: a biometrical approach. 3.ed. New York: McGraw Hill Book. 666p.

VERMEER H. 1990. Optimizing potato breeding. I. The genotypic, environment and genotypeenvironment coefficient of variation for tuber yield and other traits in potato under different experimental conditions. Euphytica 49: 229-236. 